\title{
EFEKTIVITAS PEMBELAJARAN DARING PADA MASA PANDEMI COVID-19 DI SMK NURUL JADID PAITON PROBOLINGGO
}

\author{
Rudi \\ Universitas Nurul Jadid Paiton Probolinggo \\ habibier644@gmail.com \\ Niken Septantiningtyas \\ Universitas Nurul Jadid Paiton Probolinggo \\ suksesniken@gmail.com
}

\begin{abstract}
This research was conducted to identify the implementation of online-based learning in making learning effective during the pandemic at SMK Nurul Jadid Paiton Probolinggo. This study uses a qualitative approach by collecting some data in the form of information obtained from interviews with several predetermined informants, namely the principal, vice principal, teachers, and students at SMK Nurul Jadid Paiton Probolinggo. With the hope that this research intends to describe the effectiveness of this online learning in the pandemic period which is less than two years has stopped all sectors of life. Therefore this research was conducted. And also like the implementation of online learning at SMK Nurul Jadid Paiton Probolinggo.
\end{abstract}

Keyword: online learning, Effectiveness of learning 


\section{PENDAHULUAN}

Covid 19 atau Virus Corona pertama kali muncul dikota Wuhan di Negara Cina. Penyebarannya sangat cepat dan mematikan. Penyebarannya melalui kontak langsung fisik manusia ditularkan melalui mulut, hidung dan mata. Upaya memutus mata rantai penyebaran Covid19 dilakukan pemerintah dan lembaga keagamaan dengan menerbitkan beberapa peraturan untuk dipatuhi oleh masyarakat. ${ }^{1}$ Pemerintah melakukan upaya-upaya untuk memutus mata rantai penyebaran virus covid-19, dengan memberlakukan sistem psbb, lockdown, di daerahdaerah tertentu yang memiliki potensi penyebaran virus covid-19 dengan cepat. Badan kesehatan dunia menyepakati kondisi dunia saat ini dengan memberikan pernyataan bahwa COVID-19 adalah "pandemi". Akan tetapi apa itu pandemi dan apa yang harus dipahami oleh seluruh masyarakat dunia tentang pandemi menjadi sangat penting dalam menentukan arah kebijakan dan juga sikap manusia dalam menanggulanginya. ${ }^{2}$

Munculnya wabah Covid-19 yang telah melanda lebih dari 200 negara di belahan dunia memberikan tantangan tersendiri bagi lembaglembaga pendidikan, termasuk di Indonesia yang menimbulkan dampak cukup signifikan diberbagai bidang, termasuk dalam dunia pendidikan. ${ }^{3}$ Meningkatnya angka terpapar Covid-19, menyebabkan pemerintah melalui Menteri Pendidikan dan Kebudayaan mengeluarkan kebijakan agar sistem pembelajaran harus dilakukan dengan cara jarak jauh atau daring. Pemerintah Provinsi dan Kabupaten, termasuk Pemerintah Kabupaten Probolinggo, juga menetapkan kebijakan yang sama.

Pembelajaran Daring sangat mengutamakan kepada kemandirian baik bagi guru maupun peserta didik. Guru bisa menyampaikan materi ajar kepada peserta didiknya tanpa harus bertatap muka secara langsung didalam suatu ruangan yang sama. ${ }^{5}$ Pembelajaran Daring bisa dilakukan

\footnotetext{
1 Syafrida and R. Hartati, "Bersama Melawan Virus Covid 19 di Indonesia," SALAM; J. Sos. Budaya Syar-i, vol. 7, no. 6, pp. 495-508, 2020, doi: 10.15408/sjsbs.v7i6.15325.

2 R. T. Handayani, D. Arradini, A. T. Darmayanti, A. Widiyanto, and J. T. Atmojo, "Pandemi covid-19, respon imun tubuh, dan herd immunity," J. Ilm. Permas J. Ilm. STIKES Kendal, vol. 10, no. 3, pp. 373-380, 2020.

3 Prawiyogi, A. G., Purwanugraha, A., Fakhry, G., \& Firmansyah, M. (2020). Efektifitas Pembelajaran daring Terhadap Pembelajaran Peserta didik di SDIT Cendekia Purwakarta. Jurnal Pendidikan Dasar.

4 Nabila Hilmy Zhafira, Yenny Ertika, C. (2020). Pembelajaran daring di masa Pandemi. Jurnal l Bisnis Dan Kajian Strategi Manajemen.

5 Napitupulu, R. M. (2020). Dampak pandemi Covid-19 terhadap kepuasan pembelajaran daring. Jurnal Inovasi Teknologi Pendidikan.
} 
dalam waktu yang sama maupun berbeda. Pembelajaran Daring lebih bersifat efektif dan dianggap sebagai paradigma yang paling realistis. Jenis pembelajaran ini menggunakan media sebagai alat interaksi antara guru dan peserta didik. Selanjutnya, bahan atau materi pelajaran bisa disajikan melalui media tersebut dan akan dinilai/evaluasi oleh guru.

Meskipun memiliki beberapa keunggulan dalam praktiknya, tak bisa dipungkiri bahwa Pembelajaran Daring juga memunculkan beragam masalah yang seolah-olah menurunkan implementasi proses dan hasil pembelajaran. Permasalahan utama dalam Pembelajaran Daring (PD) yakni terkait dengan masalah teknis, seperti kurang mendukungnya akses penunjang, keterbatasan guru dalam mengelola Pembelajaran Daring, dan persoalan lainnya. Salah satu faktor kurang maksimalnya pelaksanaan Pembelajaran Daring adalah anggapan bahwa guru sebagai satu-satunya sumber belajar sehingga pembelajaran berpusat pada guru (teacher centre). ${ }^{6}$ Keadaan inilah yang kemudian menimbulkan kesan bahwa pembelajaran hanya sebatas memahami dan mengulang apa yang disampaikan oleh guru dan berdampak pada rendahnya kemandirian peserta didik. ${ }^{7}$ Kemandirian belajar ini menuntut tanggung jawab yang besar pada diri peserta didik. Peran guru maupun orangtua amat menentukan kelanjutan pendidikan mereka. Sehingga tidak ada peserta didik yang terabaikan kegiatan belajarnya.

Kemandirian belajar menjadi syarat utama didalam penerapan Pembelajaran Daring. ${ }^{8}$ Kemandirian belajar hanya ditujukan kepada orang dewasa (andragogi) dengan memperhatikan empat konsep dasar diantaranya konsep diri, pengalaman, kesiapan belajar, dan perspektif terhadap waktu dan orientasi kepada belajar. ${ }^{9}$ Peserta didik pada jenjang Sekolah Menengah Kejuruan adalah peserta didik dengan rentang usia 15-18 tahun, di mana usia ini juga merupakan usia yang masih membutuhkan banyak pengawasan dan pengayoman secara intens.

Penelitian ini dilakukan untuk memperoleh temuan empirik bagi usaha peningkatan kemandirian belajar peserta didik dengan menerapkan

https://doi.org/10.21831/jitp.v7i1.32771

6 Azzahra, N. F. (2020). Mengkaji Hambatan Pembelajaran daring di Indonesia di Masa Pandemi Covid-19. Center for Indonesia Policy Studies.

7 Sari, D. R., \& Amrozi, F. (2020). Analisis Efektivitas Pembelajaran daring (PD) di Politeknik Penerbangan Surabaya. Jurnal Penelitian.

8 Suharwoto, G. (2020). Pembelajaran Online di Tengah Pandemi Covid-19, Tantangan yang Mendewasakan.

9 Sadikin, A., \& Hamidah, A. (2020). Pembelajaran Daring di Tengah Wabah Covid-19: (Online Learning in the Middle of the Covid-19 Pandemic). BIODIK: Jurnal Ilmiah Pendidikan Biologi. 
Pembelajaran Daring ditingkat Sekolah Menengah Kejuruan. Selain itu, kontribusi temuan penelitian terkait dengan implementasi Pembelajaran Daring ini akan menjadi daya tarik tersendiri bagi peneliti untuk melakukan penelitian ini.

Sejauh ini sudah banyak peneliti yang melakukan penelitian mengenai Pembelajaran Daring, baik dimasa sebelum Pandemi Covid-19 maupun sesudahnya, diantaranya adalah Hamidaturrohmah dan Tri Mulyani (2020). Dalam hasil penelitian terseut dijelaskan bahwa strategi Pembelajaran Daring yang diterapkan di SD Inklusi Semai adalah pembelajaran 5M. Pertama, Memanusiakan hubungan dengan cara membangun relasi positif antara guru, peserta didik, dan orangtua. Kedua, Memahami Konsep dengan guru memandu belajar melalui penjelasan tujuan dan proses pembelajaran pada orangtua. Ketiga, Membangun keberlanjutan dengan melakukan refleksi bersama orangtua. Keempat, Memilih tantangan dengan memberikan ragam aktivitas pembelajaran sesuai dengan kebutuhan peserta didik. Kelima, Memberdayakan konteks dengan melibatkan sumber daya apa saja di rumah sebagai sumber belajar. Berikutnya adalah Dianne Amor Kusuma (2020) menjelaskan bahwa, meskipun mayoritas peserta didik didik (94,7\%) sudah memiliki perangkat untuk menjalani PD, akan tetapi di sisi yang lain peserta didik didik merasa metode PD saat ini belum tepat karena peserta didik didik merasa tidak bisa memantau perkembangan PD dengan mudah, tidak bisa memperoleh materi pembelajaran dengan mudah juga tidak bisa mempelajari materi dengan mudah. Secara keseluruhan, baik dari sisi teknologi maupun dari sisi tenaga pengajar (dosen), peserta didik didik tidak puas dengan metode PD yang dijalaninya saat ini dan juga merasa tidak puas dengan kemampuan dosen dalam menyampaikan materi pada PD. Yang terbaru adalah Afip Miftahul Basar (2021), yang menjelaskan bahwa proses Pembelajaran Daring merupakan solusi yang dalam pelaksanaannya secara keseluruhan masih belum optimal. Ada hal yang harus diperhatikan dalam PD ini, antara lain sumber daya guru harus ditingkatkan mutunya, baik dari segi konten maupun metodologi juga dalam hal pemanfaatan teknologi informasi. Selain itu, peserta didik juga kurang aktif dalam mengikuti PD ini, baik itu disebabkan jaringan internet yang kurang stabil maupun dari segi penyediaan paket data internet yang begitu terbatas.

Dalam penelitian ini, pokok kajiannya adalah kemandirian belajar peserta didik di era Pandemi Covid-19 pada lembaga dasar, yakni di Sekolah Menengah Kejuruan. Pelaksanaan penelitian dilakukan di Sekolah Menengah Kejuruan Nurul Iman yang berada di Pondok Pesantren Nurul Jadid, Kabupaten Probolinggo. Sekolah Menengah 
Kejuruan Nurul Jadid memberikan pelayanan ekstra kepada peserta didiknya dalam mengikuti Pembelajaran Jarah Jauh di masa Pandemi Covid-19, terutama kepada kelas akhir untuk lebih aktif belajar meski dalam suasana Pandemi Covid-19. Hal ini dilakukan karena pimpinan dan seluruh tenaga pendidik tidak ingin peserta didik menyia-nyiakan waktu belajarnya menjelang kelulusan mereka. Pimpinan dan seluruh Sekolah Menengah Kejuruan Nurul Iman merespon dengan memanfaatkan media pembelajaran yang bisa diakeses kapan saja, yakni dengan menggunakan layanan internet melalui grup-grup yang tersedia di media sosial.

Dalam sejarahnya, sekolah banyak lahir dari lingkungan pondok pesantren sebagai wadah untuk memfasilitasi belajar santri sekaligus sebagai bentuk perlawanan terhadap lembaga-lembaga pendidikan model kolonial yang hanya berkutat pada pembelajaran sekuler (Nurhayati 2016). Bahkan dalam khazanah pesantren, kedudukan sekolah sangat penting sebagai lembaga yang mengakomodir seluruh mata pelajaran dengan jenjang kelas sebagaimana lembaga-lembaga formal. Kurikulum sekolah di pesantren juga bersifat lebih akomodatif dan fleksibel daripada kurikulum pendidikan formal. Meski demikian, lulusan sekolah di pesantren diharapkan memliki kompetensi keilmuan yang kaffah, baik yang bersifat ainiyah (personal) maupun kifayah (komunal). Pembahasan mengenai pendidikan pesantren juga seringkali mengundang diskusi panjang dan bahasan-bahasan yang tidak berkesudahan karena pesantren memliki daya tarik tersendiri yang mampu memikat masyarakat untuk dipelajari dan dikaji lebih dalam lagi secara berkelanjutan. Kekhasan dari pesantren sebagai lembaga keilmuan yang didalamnya meliputi sistem, metode, tata kelola, dan model adaptasi yang diimplementasikan terhadap pendidikan formal.

Ditemukan hasil penelitian yang unik dari penelitian ini, yakni peserta didik merasa lebih nyaman dalam belajar sekaligus berdiskusi. Mengikuti Pembelajaran Daring dari rumah membuat peserta didik tidak merasakan tekanan secara psikologis. Ketidakhadiran guru secara langsung atau fisik juga menyebabkan peserta didik merasa tidak canggung dalam mengajukan pertanyaan maupun menyampaikan penbisanya. Ketiadaaan penghambat fisik serta batasan ruang dan waktu menyebabkan peserta didik lebih nyaman dalam berkomunikasi di mana dalam tingkat dasar tersebut, dibutuhkan penanganan yang lebih optimal karena anak-anak cenderung abai dan lupa terhadap tugas belajarnya. Sebagaimana filosofi anak, "dunia anak adalah dunia bermain".

Pembelajaran Daring secara on line pada gilirannya menghilangkan 
rasa canggung yang pada puncaknya membuat peserta didik menjadi lebih berani untuk berekpresi dalam bertanya dan mengutarakan penbisanya secara terbuka. Pembelajaran Daring juga memiliki kelebihan tersendiri, yakni mampu menumbuhkan kemandirian belajar atau "self regulated learning" peserta didik. Penggunaan aplikasi on line berupa media sosial mampu meningkatkan kemandiri belajar.

Kekhawatiran akan terbengkalainya kegiatan pembelajaran tentu dibutuhkan kerja keras untuk menyelamatkan generasi dalam masa Pandemi Covid-19. Dari sana, keunikan penelitian ini adalah sebagai inisiatif perilaku suatu individu yang mampu dalam mengatasi berbagai masalah, memiliki kepercayaan diri serta tidak menunggu arahan dari orang lain untuk belajar. Kemandirian belajar merupakan suatu kegiatan yang dilakukan oleh peserta didik tanpa mengandalkan orang lain untuk menguasai materi atau pengetahuan dengan kesadarannya sendiri serta bisa menerapkan pengetahuannya dalam menyelesaikan masalah.

Secara teoritis, peserta didik yang memiliki motivasi belajar tinggi akan berusaha untuk mengatur waktu dan jadual belajar secara optimal sehingga mereka bisa menguasai materi mata pelajaran yang dipelajarinya. Dikemukakan oleh Walwick bahwa motivasi yang dimiliki dan dibawa individu ke dalam lingkungan belajar berpengaruh kuat terhadap apa dan bagaimana mereka belajar. ${ }^{10}$ Sementara Slavin menyatakan bahwa motivasi merupakan salah satu prasyarat yang paling penting dalam belajar dan motivasi bisa mempengaruhi hasil belajar. Uraian tersebut memberikan indikasi bahwa individu yang menerapkan kemandirian belajar akan mengalami perubahan pada kebiasaan belajar, yakni dengan cara mengatur dan mengorganisasikan dirinya sedemikian rupa sehingga bisa menentukan tujuan belajar, kebutuhan belajar, dan strategi yang digunakan dalam belajar yang mengarah kepada tercapainya tujuan yang telah dirumuskan. ${ }^{11}$ Kemandirian belajar adalah aktivitas belajar yang dilakukan oleh individu dengan kebebasannya dalam menentukan dan mengelola sendiri bahan ajar, waktu, tempat, dan memanfaatkan berbagai sumber belajar yang dibutuhkan.

Kemandirian belajar dalam penelitian ini diartikan sebagai

10 Maknuni, J. (2020). Pengaruh Media Belajar Smartphone Terhadap Belajar Peserta didik Di Era Pandemi ( The Influence of Smartphone Learning Media on Student Learning in The Era Pandemi. IDEAL: Indonesian Education Administration and Leadershio Journal.

11 Fathimah, S., Sidik, S., \& Rahman, R. (2020). Google docs sebagai solusi pengerjaan tugas kelompok dalam pembelajaran daring di tengah pandemi covid 19. Jurnal Ilmu Sosial Dan Pendidikan. 
kemampuan yang mengkondisikan peserta didik untuk bisa memiliki karakter mandiri melalui belajar mandiri. Belajar mandiri adalah suatu proses belajar di mana individu bisa berinisiatif dengan atau tanpa bantuan orang lain. ${ }^{12}$ Paradigma dalam penelitian ini adalah pandangan atau asumsi yang berdasarkan pelatihan dan pengalaman, kematangan psikologis, masalah yang dialami, dan faktor objek penelitian. ${ }^{13}$ Atas dasar pemikiran tersebut, maka kerangka berpikir dalam penelitian ini difokuskan kepada pengaruh Pembelajaran Daring terhadap kemandirian belajar peserta didik. Pembelajaran Daring adalah proses pembelajaran yang dilakukan secara tidak langsung yang bisa dilakukan melalui media internet.

Perkembangan teknologi dan informasi secara pesat pada saat ini secara langsung mendorong perkembangan pendidikan jarak jauh serta mendorong implementasi dalam pembelajaran. Dalam pembelajaran konvensional, peserta didik harus bertatap muka langsung dengan pendidik pada suatu tempat dan waktu yang sama. Hal ini berbanding dengan konsep dari Pembelajaran Daring, di mana pelajar dan guru tidak perlu bertemu tatap muka untuk melakukan proses pembelajaran, dengan memanfaatkan teknologi proses pembelajaran bisa dilakukan. ${ }^{14}$

Beberapa pakar mengungkapkan pengertian Pembelajaran Daring, diantaranya adalah G. Dogmen, Gabriel Mackenzie, E. Christensen, dan P. Rigby, O. Peter, M. Moore, B. Holmeberg. ${ }^{15}$ Menurut Dogmen, ciriciri Pembelajaran Daring adalah adanya organisasi yang mengatur cara belajar mandiri, materi pembelajaran disampaikan melalui media, dan tidak ada kontak langsung antara pengajar dengan pembelajar. ${ }^{16}$ Mackenzie, Christensen, dan Rigby mengatakan pendidikan jarak jauh merupakan metode pembelajaran yang menggunakan korespondensi sebagai alat untuk berkomunikasi antara pembelajar dengan pengajar. ${ }^{17}$

12 Knowles, M. S. (1980). THE MODERN PRACTICE OF ADULT EDUCATION, From Pedagogy to Andragogy What Is Andragogy? Business.

13 Creswell, J. W. (2003). Creswell, J.W. (2003). Chapter One, "A Framework for Design." Research Design Qualitative Quantitative and Mixed Methods Approaches. https://doi.org/10.3109/08941939.2012.723954

14 Sungkono, S. (2005). PEMBELAJARAN DARING BERBASIS TEKNOLOGI INFORMASI. MAJALAH ILMIAH PEMBELAJARAN.

15 Usman, U. (2019). KOMUNIKASI PENDIDIKAN BERBASIS BLENDED LEARNING DALAM MEMBENTUK KEMANDIRIAN BELAJAR. Jurnal Jurnalisa. https://doi.org/10.24252/jurnalisa.v4i1.5626

16 Handayani, A. S., \& Ariyanti, I. (2020). Kemandirian Belajar Matematika Peserta didik Smp Disaat Pandemi Covid-19. In UrbanGreen Conference Proceeding ....

17Christensen, J., \& Grant, M. (2007). How political change paved the way for 
Pembelajaran Daring lebih menekankan kepada peserta didiknya untuk belajar lebih mandiri. Berikut karakteristik dari Pembelajaran Daring $^{18}$ :

1. Dalam sistem Pembelajaran Daring peserta didik dan guru bekerja secara terpisah sepanjang kegiatan pembelajaran. Ini berarti bahwa peserta didik harus bisa belajar secara mandiri. Bantuan belajar yang diperoleh dari orang lain sangat terbatas.

2. Dalam sistem Pembelajaran Daring, terdapat lembaga pendidikan yang merancang dan menyiapkan bahan-bahan ajar, serta memberikan pelayanan bantuan belajar kepada peserta didik. Adanya lembaga pendidikan ini membedakan sistem Pembelajaran Daring dari proses belajar sendiri (private study) atau teach yourself programmes.

3. Dalam sistem Pembelajaran Daring, pelajaran (pengetahuan, keterampilan, dan sikap) disampaikan kepada peserta didik melalui media seperti media cetak, radio, kaset video, TV, kaset audio, slide, CD-ROM (program video dalam piringan kecil), dan sebagainya.

4. Dalam sistem Pembelajaran Daring ada upaya untuk terjadinya komunikasi dua arah antara peserta didik dan guru atau antara peserta didik dengan lembaga penyelenggara, atau juga antara peserta didik dengan peserta didik yang lain.

5. Dalam sistem Pembelajaran Daring tidak ada kelompok belajar yang bersifat tetap sepanjang masa belajarnya. Oleh karena itu peserta didik Pembelajaran Daring menerima pelajaran secara individual, bukan secara kelompok.

Kemandirian seorang peserta didik bisa dilihat dari kebiasaan yang mereka lalukan seperti merencanakan kegiatan belajar. Kemandirian belajar sangatlah penting karena berpengaruh terhadap terciptanya semangat diri untuk belajar. ${ }^{19}$ Kemandirian belajar merupakan kesiapan dari individu yang mau dan mampu untuk belajar dengan inisiatif sendiri, dengan atau tanpa bantuan pihak lain dalam hal penentuan tujuan belajar, metoda belajar, dan evaluasi hasil belajar. Berkaitan dengan hal tersebut, Sugilar merangkum penbisa Guglielmino, West \& Bentley bahwa

indigenous knowledge: The Mackenzie valley resource management act. Arctic. https://doi.org/10.14430/arctic236

18 Mashud. (2015). Pendekatan Pembelajaran Pendidikan Jasmani Olahraga dan Kesehatan di Era Abad 21. Jurnal Multilateral.

19 Hidayat, D. R., Rohaya, A., Nadine, F., \& Ramadhan, H. (2020). KEMANDIRIAN BELAJAR PESERTA DIDIK DALAM PEMBELAJARAN DARING PADA MASA PANDEMI COVID -19 Program Studi Bimbingan dan Konseling, Universitas Negeri Jakarta SELF-REGULATED LEARNING OF STUDENTS STUDYING ONLINE. PERSPEKTIF Ilmu Pendidikan. 
kemandirian belajar merupakan kesiapan individu untuk mau dan mampu belajar dengan inisiatif sendiri meski tanpa bantuan pihak lain. Karakteristik individu yang memiliki kesiapan belajar mandiri dicirikan dengan ${ }^{20}$ :

1. Kecintaan terhadap belajar

2. Kepercayaan diri sebagai peserta didik

3. Keterbukaan terhadap tantangan belajar

4. Sifat ingin tahu

5. Pemahaman diri dalam keadaan belajar

6. Menerima tanggung jawab untuk kegiatan belajarnya.

Dalam kemandirian belajar, inisiatif merupakan indikator yang sangat mendasar. ${ }^{21}$ Dalam pengertiannya yang lebih luas, kemandirian belajar mendeskripsikan sebuah proses di mana individu mengambil inisiatif sendiri, dengan atau tanpa bantuan orang lain, untuk mendiagnosis kebutuhan belajar, memformulasikan tujuan belajar, mengidentifikasi sumber belajar, memilih dan menentukan pendekatan strategi belajar, dan melakukan evaluasi hasil belajar yang dicapai.

Kemandirian belajar menuntut tanggung jawab yang besar pada diri peserta ajar sehingga peserta ajar berusaha melakukan berbagai kegiatan untuk tercapainya tujuan belajar. Kemandirian belajar sebagai bentuk belajar yang memiliki tanggung jawab utama untuk merencanakan, melaksanakan, dan mengevaluasi usahanya. Dengan begitu, kemandirian belajar perlu diberikan kepada peserta ajar susaha mereka memiliki tanggung jawab dalam mengatur dan mendisiplinkan dirinya dalam mengembangkan kemampuan belajar atas kemauan sendiri. ${ }^{22}$ Disamping tanggung jawab, motivasi yang tinggi dari peserta didik sangat diperlukan dalam kemandirian belajar. Lebih jauh lagi, dalam sistem belajar jarak jauh, motivasi memegang peranan sangat penting karena peserta ajar dituntut untuk belajar mandiri.

Adanya virus COVID-19 di Indonesia saat ini berdampak bagi seluruh masyarakat. Menurut kompas, (28/03/2020) dampak virus COVID-19 terjadi diberbagai bidang seperti sosial, ekonomi, pariwisata

20 ZULFIKAR, Z. (2020). Rekonstruksi Pendidikan Keluarga Pada Masa Pandemi (Studi Pada Walimurid SMPI Al Hasanah Kota Bengkulu). Annizom.

21 Sulastrini, S., \& Muslihati, M. (2020). Rancangan Implementasi Kemandirian Belajar dalam Konteks Pandemi Covid-19 berdasarkan Perspektif Freedom to Learn Rogers. Prosiding Seminar Bimbingan Dan Konseling.

22 Jusuf, H., Sobari, A., \& Fathoni, M. (2020). Pengaruh Pembelajaran daring Bagi Peserta didik SMA Di Era Covid-19. Jurnal Kajian Ilmiah. https://doi.org/10.31599/jki.v1i1.212. 
dan pendidikan. Surat Edaran (SE) yang dikeluarkan pemerintah pada 18 Maret 2020 segala kegiatan didalam dan diluar ruangan di semua sektor sementara waktu ditunda terutama pada bidang pendidikan. ${ }^{23}$ Lembaga pendidikan sekolah/ perguruan tinggi sebagai ujung tombak pelayanan pendidikan pada level paling bawah. Para pimpinan Perguruan tingi/kepala sekolah dipaksa oleh keadaan untuk sesegera membuat suatu keputusan atau kebijakan teknis untuk merespon kebijakan surat edaran perintah dari mendikbud yang mengharuskan layanan pendidikakan atau "pembelajaran dari rumah" mulai dari Taman kanak-kanak sampai Perguruan tinggi. Hal ini dilakukan untuk memutus mata rantai penyebaran COVID-19. Sebagai gantinya kegiatan pembelajaran dilakukan secara online untuk semua jenjang pendidikan. Kondisi demikian menuntut lembaga pendidikan untuk melakukan inovasi dalam proses pembelajaran.

Terdapat tiga pilar utama pada pembelajaran di sekolah. Pertama, filosofis, yakni sebagai fondasi bahwa belajar di sekolah hukumnya adalah fardu ain (wajib personal) untuk dipertahankan sebagai lembaga yang "tafaqquh fiddin" melalui sumber belajar yang terdiri dari ide, citacita, dan sebagai simbol keagungan sekolah yang terdapat di pesantren. Kedua, sosiologis, yakni sebagai rujukan bahwa sekolah tidak berada pada ruang hampa (vacuum sepace), akan tetapi bagian dari sistem sosial yang luas dan dinamis, sehingga eksistensi sekolah tidak sekedar sebagai pelengkap, tetapi menjadi pilihan utama. Ketiga, yuridis, yakni sebagai dasar mengembangkan kearifan bahwa di Indonesia berlaku sistem pendidikan nasional, sehingga jenis, dan bentuk perjenjangan satuan pendidikan yang namanya sekolah tersebut harus menyesuaikan dengan peraturan pendidikan yang ditetapkan dalam undang-undang. ${ }^{24}$ Oleh karena itu, terlepas dari wabah covid-19, pembelajaran harus terus diselenggarakan karena sebagai amanah dan kewajiban seluurh umat manusia.

Adanya wabah covid-19 secara mendadak dan cepat membuat sekolah dan perguruan tinggi mengikuti alur dengan memaksakan diri menggunakan media daring, akan tetapi penggunaan teknologi dan media daring justru mencetak banyak varians masalah yang menghambat

23 W. A. F. Dewi, "Dampak COVID-19 terhadap Implementasi Pembelajaran Daring di Sekolah Dasar," J. Ilmu Pendidik., vol. 2, no. 1, pp. 55-61, 2020, doi: 10.31004/edukatif.v2i1.89.

24 Peserta didiknto, Peserta didiknto. 2016. "DESAIN MUTU PENDIDIKAN PESANTREN." KARSA: Jurnal Sosial Dan Budaya Keislaman. https://doi.org/10.19105/karsa.v23i2.726. 
terlaksananya efektivitas pembelajaran dengan metode daring. ${ }^{25}$ Varian tersebut sebut misalnya pekembangan teknologi yang sangat amat digandrungi oleh masayarkat Indonesia, baik muda mudinya, dewasa dan anak-anak remaja semua berbondong-bondong menggunakan kecanggihan teknologi sebagai media komunikasi. Hal ini bisa dilihat pada fenomena Media sosial memberi manfaat kepada penggunanya, seperti komunikasi, kolaborasi, komunitas, dan kesepakatan untuk kecerdasaran kolektif. Media sosial bukan sekedar tren atau gaya hidup, tetapi media sosial menjadi bagian dari kehidupan masyarakat saat ini. Dilihat dari hasil GWI (Global Web Index) di tahun 2014, warga negara Indonesia adalah negara dengan penggunaan tertinggi dalam media sosial, prosentasenya adalah $79,7 \%{ }^{26}$

Oleh karena itu, guru harus mampu menggunakan metode dan pendekatan serta penggunaan sarana dan prasarana yang tepat agar proses belajar mengajar menjadi menarik dan menyenangkan. Memberikan ruang yang seluas-luasnya bagi peserta didik untuk berkrativitas dan terlibat aktif sepanjang proses pembelajaran. Hingga ranak kognitif, afekti dan psikomotor peserta didik bisa tumbuh berkembang secara maksimal dan bersamaan tanpa mengalami pengkerdilan. ${ }^{27}$ Dengan demikian, peserta didik mendapatkan haknya sekalipun tentu terdapat beberapa kekurangan dalam pembelajaran daring. Keadaan ini tidak menutup kemungkinan karena pembelajaran tatap muka belum bisa digantikan oleh media apapun.

Kebijakan pemerintah dalam hal ini harus menerpakan physical distancing, dimana kebijakan tersebut mengharuskan masyarakat untuk lebih berdiam diri dirumah masing-masing, dalam jenjang dunia pendidikan di adakannya sistem daring dengan belajar dari rumah tatap muka melalaui media elektronika. Setiap lembaga-lembaga pendidikanpun memiliki keefektivan dalam belajar-mengajar. Di SMK Nurul Jadid yang notabene pelajarnya berasal dari kalangan santri untuk mengoperasikan media elektronik masih sangat terbatas, pada masa

25 T. P. R. N. Hapsari and A. S. Fitria, "EFEKTIVITAS PEMBELAJARAN DARING MATA KULIAH EVALUASI PENGAJARAN BAHASA DAN SASTRA INDONESIA MASA PANDEMI COVID-19," J. Ilm. Semant., vol. 2, no. 01, pp. 1120, 2020.

26 Tenika Illananingtyas \& Ellyda Retpitasari "FENOMENA HIJRAH KEKINIAN GENERASI Z KOTA KEDIR,I" Tafaqqub: Jurnal Penelitian dan kajian keislaman Volume 9, Nomor 2, Desember 2021 ; p-ISSN 2338-3186; e-ISSN 2549-1873; 185-200

27 A. M. Saifulloh and M. Darwis, "MANAJEMEN PEMBELAJARAN DALAM MENINGKATKAN EFEKTIVITAS PROSES BELAJAR MENGAJAR DI MASA PANDEMI COVID-19 Ahmad,” Bidayatuna, vol. 03, no. 02, pp. 286-311, 2020. 
pandemi covid-19 SMK Nurul Jadid bernaungan terhadap Pondok Pesantren Nurul Jadid. terkait kebijakan dari pemerintah Pondok Pesantren Nurul Jadid sudah mengantisipasi pandemi tersebut.

Seiring berjalannya waktu pandemi covid-19 tidak berkesudahan pihak pesantren pun memulangkan semua santri secara bertahap sesuai asal daerah masing-masing. Kepulangan santri lebih awal ini lantas tidak memutus harapan para pelajar untuk tetap bisa kreatif di masa pandemi ini, Pondok Pesantren Nurul Jadid mengatasi situasi ini dengan cara belajar-mengajar ini dari rumah sesuai anjuran dari pemerintah, tidak berhenti di situ Nurul Jadid juga mengadakan pengajian kitab secara online, meskipun keefektivan sistem ini tidak sepenuhnya berjalan dengan baik sebagai seorang pelajar dan juga santri harus tetap bisa bertahan dalam situasi dan kondisi apapun.

\section{KAJIAN PUSTAKA}

Pembelajaran daring merupakan pembelajaran yang menggunakan jaringan internet dengan aksesibilitas, konektivitas, fleksibilitas, dan kemampuan untuk memunculkan berbagai jenis interaksi pembelajaran. ${ }^{28}$ Pembelajaran daring pada dasarnya adalah pembelajaran yang dilakukan secara virtual melalui aplikasi virtual yang tersedia. ${ }^{29}$ Walaupun demikian, pembelajaran daring harus tetap memperhatikan kompetensi yang akan diajarkan. ${ }^{30}$ Dengan adanya pembelajaran sistem daring di tengah-tengah masa pandemi virus covid-19, para pelajar di tuntut tetap bisa kreatif dalam belajar dengan sistem daring yang meliputi berbagai aspek aplikasi agar memudahkan untuk mengakses berbagai materi pelajaran.

Oleh Oleh karena itu, diperlukan suatu inovasi pembelajaran salah satunya dengan pembelajaran yang berbasis teknologi agar tampilan dan gaya belajar menjadi lebih menarik, membuat peserta didik terhindar dari rasa jenuh dan bosan saat mengikuti pembelajaran. ${ }^{31}$ Maka dalam hal ini

28 A. Sadikin and A. Hamidah, "Pembelajaran Daring di Tengah Wabah Covid-19 ( Online Learning in the Middle of the Covid-19 Pandemic )," BIODIK J. Ilm. Pendidik. Biol., vol. 6, no. 02, pp. 214-224, 2020.

29 A. S. Syarifudin, "IMPELEMENTASI PEMBELAJARAN DARING UNTUK MENINGKATKAN MUTU PENDIDIKAN SEBAGAI DAMPAK DITERAPKANNYA SOCIAL DISTANCING," J. Pendidik. Bhs. dan Sastra Indones. pemerintah, vol. 5, no. 1, pp. 31-34, 2020.

30 R. Yunitasari and U. Hanifah, "Pengaruh Pembelajaran Daring terhadap Minat Belajar Peserta didik pada Masa COVID-19," Ria Yunitasari1, Umi Hanifah2, vol. 2, no. 3, pp. 232-243, 2020.

31 N. Septantiningtyas, "PENGARUH PEMBELAJARAN DARING DENGAN APLIKASI GOOGLE CLASS TERHADAP HASIL BELAJAR MAHASISWA," J. Pendidik. agama islan edureligia, vol. 2, no. 2, pp. 1-5, 2018. 
guru harus mampu merubah gaya komunikasi di era pandemi covid-19, yang biasanya guru berkomunikasi satu arah dan biasanya terjadi diskusi dengan peserta didik, pada masa pandemi covid-19 sekarang ini membuat peserta didik kurang aktif dan kurang termotivasi dalam berdiskusi secara online. Maka dari itu guru harus sigap dan mampu membangun semangat peserta didik melalui komunikasi yang baik. ${ }^{32}$

Pembelajaran bersifat mandiri dan interaktivitas yang tinggi, mampu meningkatkan tingkat ingatan, memberikan lebih banyak pengalaman belajar, dengan teks, audio, video dan animasi yang semuanya digunakan untuk menyampaikan informasi, dan juga memberikan kemudahan menyampaikan, memperbarui isi, mengunduh, para peserta didik juga bisa mengirim email kepada peserta didik lain, mengirim komentar pada forum diskusi, memakai ruang chat, hingga link videoconference untuk berkomunikasi langsung. ${ }^{33}$

Dalam hal ini pelajar masih bisa mengembangkan kemampuan nya dalam hal belajar di tengah masa pandemi covid-19 dengan adanya berbagai aplikasi memudahkan pelajar untuk tetap bisa berinteraksi secara online. Aplikasi yang tersediapun bermacam-macam, mulai dari aplikasi yang gratis hingga aplikasi yang berbayar, semua itu demi memudahkan pengguna untuk berinteraksi secara online dalam proses belajar-mengajar.

Penggunaan Teknologi Informasi dan Komunikasi (TIK) didalam dunia pendidikan terus berkembang dalam berbagai strategi dan pola, yang pada dasarnya bisa dikelompokkan ke dalam sistem e-learning (electronic learning) sebagai model pembelajaran yang memanfaatkan perangkat elektronik dan media digital, maupun mobile learning sebagai bentuk pembelajaran yang memanfaatkan perangkat dan teknologi komunikasi bergerak ${ }^{34}$.

Dengan adanya berbagai aplikasi yang tersedia bisa di manfaatkan oleh pengguna sebagai model pembelajaran di tengah-tengah masa pandemi covid-19. Teknologi bisa dimanfaatkan dalam kegiatan proses

32 Mastura and R. Santaria, "Dampak Pandemi Covid-19 terhadap Proses Pengajaran bagi Guru dan Peserta didik," J. Stud. Guru dan Pembelajaran, vol. 3, no. 2, pp. 289-295, 2020.

33 Ericha Windhiyana Pratiwi, "DAMPAK COVID-19 TERHADAP KEGIATAN PEMBELAJARAN ONLINE DI SEBUAH PERGURUAN TINGGI KRISTEN DI INDONESIA," Perspek.t. Ilmu Pendidik., vol. 34, no. 1, pp. 1-8, 2020, doi: 10.21009/pip.341.1.

34 B. Warsita, "MOBILE LEARNING SEBAGAI MODEL PEMBELAJARAN YANG EFEKTIF DAN INOVATIF,” J. Teknodik, vol. XIV, no. 1, pp. 62-73, 2010. 
belajar mengajar, yang bisa dikatakan merupakan pergantian dari cara konvensional menjadi ke modern ${ }^{35}$ Teknologi juga bisa di jadikan solusi agar lebih mudah mengakses suatu informasi yang di butuhkan. Akan tetapi, Pelaksanaan pembelajaran daring bukan tanpa masalah.

Di beberapa negara, dilaporkan bahwa diantara mereka yang mengadopsi pembelajaran daring, rata-rata manfaat sebenarnya jauh lebih kecil daripada yang diharapkan. Masalah jaringan, kurangnya pelatihan, dan kurangnya kesadaran dinyatakan sebagai tantangan utama yang dihadapi oleh pendidik. ${ }^{36}$

Dalam hal keterbatasan penguasaan IT, guru bisa menggunakan teknologi yang pengoperasiannya lebih sederhana, seperti aplikasi whatsapp. Akan tetapi, sedikit demi sedikit guru harus meningkatkan kompetensi IT-nya, antara lain dengan mengikuti workshop terkait, bertanya kepada guru-guru lain yang memiliki kemampuan lebih di bidang IT. ${ }^{37}$

Pada konsep pembelajaran tersebut mobile learning membawa manfaat ketersediaan materi pembelajaran yang bisa di akses setiap saat dan visualisasi materi yang menarik. Kegiatan pembelajaran yang dilakukan dengan efektif oleh guru bisa mendukung proses pembelajaran yang menyenangkan. Hal ini disebabkan, melalui proses pembelajaran peserta didik akan menbisakan pembelajaran yang efektif dan dukungan untuk berkembang.

Oleh karena itu, peserta didik perlu diberi rangsangan, dorongan dan dukungan berupa program kegiatan pembelajaran yang menarik, efektif, dan menyenangkan. Efektivitas pembelajaran merupakan takaran keberhasilan suatu sekolah dalam menyelenggarakan pendidikan, sehingga sangat diperlukan adanya upaya pembelajaran yang mampu membangkitkan minat dan kemauan peserta didik dalam kegiatan pembelajaran untuk mengembangkan seluruh potensi dalam diri peserta didik.

SMK Nurul Jadid merupakan sekolah yang berada dinaungan Pondok Pesantren Nurul Jadid, tentulah difikirkan dengan matang oleh

35 O. I. Handarini, S. S. Wulandari, and Program, "Pembelajaran Daring Sebagai Upaya Study From Home (SFH) Selama Pandemi Covid 19 Oktafia," J. Pendidik. Adm. Perkantoran, vol. 8, no. 3, pp. 496-503, 2020.

36 P. Wahyono, H. Husamah, and A. S. Budi, "Guru profesional di masa pandemi COVID-19: Review implementasi, tantangan, dan solusi pembelajaran daring Poncojari," J. Pendidik. PROFESI GURU, vol. 1, no. 1, pp. 51-65, 2020.

37 Asmuni, "Problematika Pembelajaran Daring di Masa Pandemi Covid-19 dan Solusi Pemecahannya," Penelit. dan Pengemb. Pendidik., vol. 7, no. 4, pp. 281-288, 2020 
pihak-pihak Pondok Pesantren. Adanya kebijakan dari pemerintah dengan adanya model pembelajaran sistem daring atau online di tengahtengah masa pandemi covid-19 untuk sistem pembelajaran ini, tentulah masih ada kendala-kendala terkait sistem dan teknis pelaksanaanya, akan tetapi tidak membakar semangat dan kemauan para pelajar yang notabene berstatus santri untuk tetap bisa mengasah kemampuan dan kreativitas para pelajar, semua itu untuk tetap bisa melatih diri dan mengembangkan kemapuannya. Pelajar sudah bisa mengakses berbagai materi dengan adanya aplikasi-aplikasi yang tersedia agar memudahkan para pelajar tetap bisa berinteraksi secara online.

\section{METODE PENELITIAN}

Penelitian ini menggunakan pendekatan kualitatif jenis studi kasus. dalam penelitian ini, terkait kebijakan pemerintah dengan diberlakukannya model pembelajaran sistem daring atau online. Maka dari itu proses penelitian ini dari awal hingga akhir untuk menjawab tujuan dari penelitian dengan cara mengumpulkan berbagai data. Peneliti mengumpulkan beberapa data yang berupa informasi yang di bisakan dari hasil wawancara dengan beberapa informan yang telah di tentukan, yakni kepala sekolah, wakil kepala sekolah, guru sebanyak 10, dan 50 peserta didik di SMK Nurul Jadid Paiton Probolinggo. Sedangkan observasi dan dokumentasi dilakukan terhadap kegiatan pembelajaran yang dilakukan oleh guru dengan memanfaatkan mobile learning. Analisis datanya dilakukan dengan penyajian data, reduksi data, dan penarikan kesimpulan.

\section{HASIL PENELITIAN}

Berdasarkan hasil dari penelitian yang dilakukan pada SMK Nurul jadid Paiton Probolinggo tentang efektifitas pembelajaran daring dimasa pandemi covid-19 diukur dari implementasinya untuk berjalannya pelaksanaan kegiatan belajar-mengajar dengan baik tentunya membutuhkan media elektronik berupa laptop, smart phone dan juga sitem penggunaan terhadap pelajar,dan juga media yang berupa aplikasi seperti zoom untuk menyediakan fasilitas interaksi para pelajar secara online agar pelaksanaan kegiatan pembelajaran bisa berjalan dengan efektiv.melalui aplikasi ini peserta didik bisa berinteraksi secara online proses ini di lakukan dengan tahap diskusi, untuk menentukan metode penyampaian materi di masa pandemi covid-19.

Pembelajaran daring yang di lakukan melibatkan semua guru dan peserta didik, proses yang di lakukan dengan pola diskusi untuk 
menentukan konsep penyampaian materi tekhnik, metode, media selama melakukan kegiatan belajar-mengajar di masa pandemi covid-19 tekhnik dan juga metode yang di gunakan sesuai porsinya masing-masing terkait metode pembelajaran sesuai kelas dan tingkatan masing-masing.dengan adanya fasilitas berupa aplikasi ini agar lebih memudahkan para peserta didik untuk berinteraksi secara online dan diskusi online.

Untuk penilaian dari guru terkait sistem pembelajaran daring ini yakni mengikuti proses pembelajaran daring ini sampai dengan 50\%. di akhir semester para guru memberikan penilaian kepada para peserta didiknya yang di nyatakan sudah memenuhi kriteria seperti mengikuti kegiatan pembelajaran daring yang sudah di tentukan dan juga menyetorkan tugas-tugas dari guru-guru terkait melalui aplikasi whatsap ataupun telegram penelitian ini bertujuan untuk memperoleh informasi terkait dampak covid-19 terkait pengimplementasianya.

Sistem pembelajaran daring di SMK nurul jadid paiton probolinggo agar sistem pembelajaran daring bisa berjalan dengan baik dan efektiv pemberian tugas secara daring kepada para peserta didik melalui whatsapp gruop dan juga telegram yang di nilai efektiv dalam masa pandemi covid-19.pada saat ini para guru memiliki cara tersendiri untuk menyampaikan materi kepada para peserta didik ada yang menggunakan persentasi secara online,ada juga yang menyampaikan materi dari rumah seperti biasa nya lalu kemudian di videokan dan di kirim melalui group whatsapp dan juga telegram.

Kegiatan pembelajaran yang di lakukan secara efektif oleh guru yang ada tentu nya bisa mendukung proses kegiatan pembelajaran yang menyenangkan di masa pandemi covid-19 ini. Oleh karenanya peserta didik sangatlah perlu di berikan motivasi dan dukungan dari para guru berupa program kegiatan pembelajaran yang menarik dan menyenangkan di masa pandemi ini. Efektivitas pembelajaran adalah tolak ukur suatu keberhasilan pada sekolah yang menyelenggarakan pendidikan.

Maka dari ini sangat di perlukan upaya-upaya agar tetap berjalan nya kegiatan pembelajaran di masa pandemi covid-19 ini untuk tetap menumbuhkan dan membangkitkan semangat para pelajar untuk terus melatih diri dan menggali potensi yang ada. Hal ini dibuktikan dengan diraihnya piagam penghargaan oleh Sekolah Menengah Kejuruan (SKM) PP Nurul Jadid Paiton dari Southeast Asian Ministers of Education Organization (SEAMEO).

Serah terima piagam penghargaan oleh pihak SEAMEO kepada SMKNJ sebagai bentuk apresiasi Award dari SEAMOLEC dan sebagai 
pengakuan atas penerapan model program Pembelajaran Daring yang di lakukan seluruh Indonesia. Sehingga mendorong SMK Nurul Jadid Kabupaten Probolinggo untuk terus mengoptimalkan dan meningkatkan kempetensi sumber daya manusia (SDM) dalam pengembangan media komunikasi, informasi dan edukasi/pembelajaran. ${ }^{38}$

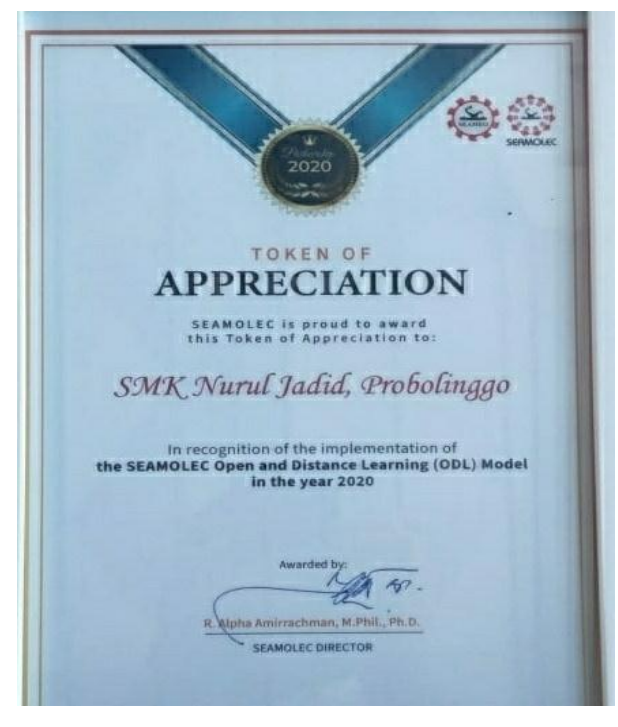

(Gambar: 1)

Piagam Penghargaan SMKNJ)

Hal ini merupakan bukti kerja nyata di mana SMK Nurul Jadid terus bergerak dan berproses meeskipun di masa pandemi covid 2019, prinsipnya berbuat akan menjadi lebih baik daripada diam \& bepangku tangan pasrah tanda menyerah. Akan tetapi demikian sistem pembelajaran daring yang di berlakukan tidak sepenuhnya berjalan dengan baik terkait akses internet, jaringan atau sinyal masih menjadi kendala terhadap peserta didik pihak sekolah sudah melakukan upaya sistem pembelajaran daring ini agar bisa berjalan dengan efektif di masa pandemi covid-19 ini. Dan kendala ini terus dibenahi sambil berjalan bersama waktu.

Melalui berbagai layanan menu dalam Pembelajaran Daring ini terdiri dari video, voice, diskusi, dan demonstrasi, guru mengharapkan proses pembelajaran di luar kelas akan menjadi lebih kontekstual,

38 http://www.teropongtimur.co.id/2020/12/smk-nurul-jadid-menbisa-piagamdimasa.html. Penyerahan piagam penghargaan yang bertempat di Grand Savero Hotel Bogor, selasa, pada 07/12/2020 
bervariatif, menarik, efisien dan menyenangkan. Sebagaimana yang disampaikan oleh guru "bahwa kemajuan teknologi dan pemanfaatan internet menjadi acuan dunia pendidikan Indonesia sejak tahun 2013, Kemendikbud sudah mengembangkan kurikulum baru dan sistem yang semuanya serba di-online-kan serta mengembangkan pendidikan menuju masa depan Indonesia Emas di tahun 2045 nanti". ${ }^{39}$

Dengan adanya pemanfaatan Pembelajaran Daring yang dilakukan oleh guru di sekolah, peserta didik diharapkan bisa mengakses kembali materi yang telah atau akan dipelajari melalui handphone ketika berada di rumah. Sehingga peserta didik merasa nyaman dalam belajarnya.

Hasil penelitian yang dilakukan pada bulan Juli sampai Agustus 2021 di SMK Nurul Jadid Paiton Probolinggo menunjukkan bahwa terdapat berbagai cara yang dilakukan oleh para guru dalam memanfaatkan Pembelajaran Daring sebagai media pembelajaran yang lebih efektif. Pembelajaran dengan menggunakan media sosial yang sudah dilakukan oleh guru tentunya merupakan suatu usaha yang cukup realistis mengingat pembelajaran langsung tidak diperkenankan.

Untuk meningkatkan minat dan bakat serta suasana belajar yang kondusif dan menyenangkan, guru memaksimalkan Pembelajaran Daring. Pembelajaran dengan memanfaatkan jaringan internet dapat dilaksanakan manakala guru tersebut memliki kompetensi yang baik dan bisa memahami bahwa peran utama seorang guru bukan sekedar mengajar, akan tetapi juga menciptakan lingkungan belajar yang kondusif dan menyenangkan bagi peserta didiknya. Berpijak pada hasil observasi dan wawancara, menu yang sering dimanfaatkan guru dalam proses pembelajaran yakni video dan diskusi.

Sementara untuk menu lainnya guru belum pernah mencobakan dalam proses pembelajaran karena masih dalam tahapan mempelajari lebih lanjut dan merencakan sesuai dengan materi yang dibutuhkan pada pembelajaran. Guru mengaku tidak mengalami kesulitan sama sekali ketika mengaplikasikan keempat menu tersebut karena materi yang diperlukan sudah dikelompokkan berdasarkan kelas, mata pelajaran dan topik yang telah ditentukan. Keadaan ini sangatlah memudahkan guru dalam memilah dan menyeleksi materi yang sesuai dengan tujuan pembelajaran yang ingin dicapai oleh peserta didik.

Seluruh materi yang disampaikan tentu mengacu pada buku ajar yang telah disediakan sebelumnya di buku-buku paket dari pemerintah.

\footnotetext{
${ }^{39}$ Wawancara dengan Guru SMKNJ Nurul Iman 2021
} 
Dengan video, guru lebih leluasa menjelaskan materi. Hal ini disampaikan bahwa "menu yang paling sering dimanfaatkan guru sebagai media pembelajaran dari daring yakni video. Video merupakan menu yang bisa menjelaskan berbagai konten pembelajaran seperti audio, animasi, visual dan audio visual." ${ }^{40}$

Guru memanfaatkan BSE dikarenakan tidak semua peserta didik memliki buku cetak dan apabila terdapat materi yang perlu dijelaskan melalui gambar dari buku-buku tersebut. Bersamaan dengan itu, menjelasakan bahwa "berikutnya media lainnya yang sering dimanfaatkan adalah BSE (Buku Sekolah Elektronik) dan Kolom Soal melalui google drive. BSE adalah buku-buku yang disediakan dalam bentuk file PDF elektronik yang bisa diunduh, dicetak, bahkan diperbanyak oleh siapa pun." ${ }^{41}$

Cara pemanfaatan menu Kolom Soal bisa disesuaikan dengan penilaian harian yakni manakala sudah menyelesaikan satu subtema atau satu tema ketika membuat penilaian akhir (evaluasi). Menu Kolom Soal bisa pula digunakan guru untuk mencari referensi dalam membuat lembar kerja peserta didik, soal ulangan da mengajukan pertanyaan langsung ketika pembelajaran berlangsung untuk memancing peserta didik untuk berpikir kritis. Sedangkan menu Kolom Soal merupakan kumpulan soal-soal berdasarkan suatu topik tertetu beserta pembahasannya. ${ }^{42}$

Dalam hasil observasi yang dilakukan, pemanfaatan keempat menu tersebut bisa dikombinasikan selama proses pembelajaran berlangsung, tetapi bisa juga diterapkan secara mandiri khusus satu menu saja. Dalam menerapkan pembelajaran berbasis internet yang memanfaatkan menu Video, BSE dan Kolom Soal secara otomatis guru akan bereksperimen dengan berbagai model pembelajaran yang sesuai dengan topik. Model pembelajaran dengan media daring yang digunakan oleh guru kelas XII telah menunjukkan pembelajaran yang interaktif, dimana pada proses pembelajaran lebih berpusat pada peserta didik. Pemanfaatan konten dalam proses pembelajaran menunjukkan adanya pengalaman belajar yang berbeda bagi peserta didik di masing-masing pertemuan. Peserta didik merasa tertarik, semangat dan senang selama kegiatan pembelajaran berlangsung.

Setelah dikaji, berbagai metode yang digunakan oleh guru dalam

\footnotetext{
${ }^{40}$ Wawancara dengan Guru SMKNJ Abdul Manaf 2021

${ }^{41}$ Wawancara dengan Guru SMKNJ Mahfudz 2021

${ }^{42}$ Wawancara dengan Guru SMKNJ Nurul Iman 2021
} 
memanfaatkan media sosial sebagai model pembelajaran daring pada saat proses pembelajaran dapat dikelompokkan sebagai berikut: ${ }^{43}$

1. Mukadimah

Pada bagian pertama ini guru mengucapkan salam pembuka yang disusul dengan absensi peserta didik untuk memastika peserta didiknya sudah siap menerima pelajaran online.

2. Demonstrasi/ceramah

Kegiatan pembelajaran dengan metode demonstrasi dilakuan oleh guru untuk menjelaskan materi-materi yang sifatnya umum dan teoritis seperti pada materi Pendidikan Kewarganegaraan, Sejarah Nasional, siklus makhluk hidup. Guru menjelaskan materi melalui video, gambar, atau audio sesuai dengan topik pembelajaran yang dipelajari dan tersedia. Perangkat yang digunakan guru dapat berupa handphone, laptop dan LCD proyektor. Selanjutnya guru memberi tugas kepada peserta didiknya.

3. Diskusi/musyawarah

Melalui metode diskusi, guru berusaha meningkatkan pemahaman peserta didik terhadap materi yang dipelajari. Di awal pembelajaran guru dapat penjelasan yang terdapat dalam BSE atau menayangkan sebuah video kemudian memberi tugas untuk menyelesaikan lembar kerja yang telah diberikan guru lalu mempresentasikan hasil diskusi.

4. Tugas Individu

Metode pembelajaran ini bertujuan untuk meningkatkan pemahaman peserta didik secara mandiri. Setelah menyaksikan video pembelajaran atau penjelasan guru, peserta didik diberikan tugas tertulis yang harus dikerjakan secara individu/mandiri. Tugas yang diberikan bisa berupa tugas di luar jam pelajaran.

Dari penjelasan di atas, kemandirian belajar peserta didik merupakan kegiatan yang terdorong oleh suatu kemauan, pilihan serta tanggung jawab sendiri tanpa menggantungkan diri terhadap orang lain. Pendidikan Jarak Jauh tersebut merupakan bentuk pendidikan yang memberikan kesempatan kepada pembelajarnya untuk belajar secara terpisah dari pengajarnya. Akan tetapi ada kemungkinan untuk acara pertemuan antara pengajar dan pembelajar hanya dilakukan kalau ada peristiwa yang istimewa atau untuk melakukan tugas-tugas tertentu saja.

Dengan Pembelajaran Daring, peserta didik tidak terkendala waktu dan tempat di mana mereka bisa mengikuti pembelajaran dari rumah masing-masing maupun dari tempat di mana saja mereka berada. Dengan

\footnotetext{
${ }^{43}$ Wawancara dengan Guru SMKNJ Abdul Manaf 2021
} 
Pembelajaran Daring, guru memberikan materi melalui sosial media sebagai media pembelajaran yang efektif, yang bisa diakses di mana pun dan kapan pun tidak terikat oleh ruang dan waktu. Keadaan ini membuat peserta didik bisa secara leluasa memilih mata pelajaran yang dikuti dan tugas mana yang harus dikerjakan terlebih dahulu.

\section{KESIMPULAN}

Berdasarkan hasil penelitian diatas, bisa di simpulkan bahwa efektivitas sistem pembelajaran dimasa pandemi covid-19 sangatlah menjadi solusi pada saat proses belajar-mengajar.Kebijakan pemerintah untuk tetap beraktivitas dirumah dan tidak di perkenankan melakukan aktivitas secara berkelompok dengan tetap physical distancing bertujuan untuk memutus rantai penyebaran virus covid-19. Hasil penelitian ini menunjukkan bahwa, keefektifan proses pembelajaran daring di SMK nurul jadid sangatlah menjadi solusi untuk tetap berlangsungnya proses belajar-mengajar, meskipun tidak sepenuh nya sistem daring ini berjalan dengan baik dan SMK nurul jadid melakukan upaya-upaya agar peserta didik tetap bisa belajar dan kreatif di masa pandemi covid-19.

\section{DAFTAR PUSTAKA}

Syafrida and R. Hartati, "Bersama Melawan Virus Covid 19 di Indonesia," SALAM; J. Sos. Budaya Syar-i, vol. 7, no. 6, pp. 495508, 2020, doi: 10.15408/sjsbs.v7i6.15325.

R. T. Handayani, D. Arradini, A. T. Darmayanti, A. Widiyanto, and J. T. Atmojo, "Pandemi covid-19, respon imun tubuh, dan herd immunity," J. Ilm. Permas J. Ilm. STIKES Kendal, vol. 10, no. 3, pp. 373-380, 2020.

W. A. F. Dewi, "Dampak COVID-19 terhadap Implementasi Pembelajaran Daring di Sekolah Dasar," J. Ilmu Pendidik., vol. 2, no. 1, pp. 55-61, 2020, doi: 10.31004/edukatif.v2i1.89.

S. Ningsih, "IMPLEMENTASI PEMBELAJARAN DARING BERBASIS EDMODO PADA MATA KULIAH EVALUASI PROGRAM KEPELATIHAN DI MASA PANDEMI COVID19," J. Teknol. Pendidik., vol. 13, no. 2, pp. 126-136, 2020.

T. P. R. N. Hapsari and A. S. Fitria, "EFEKTIVITAS PEMBELAJARAN DARING MATA KULIAH EVALUASI PENGAJARAN BAHASA DAN SASTRA INDONESIA MASA PANDEMI COVID-19," J. Ilm. Semant., vol. 2, no. 01, pp. 11-20, 2020. 
Tenika Illananingtyas \& Ellyda Retpitasari "FENOMENA HIJRAH KEKINIAN GENERASI Z KOTA KEDIR,I” Tafaqquh: Jurnal Penelitian dan kajian keislaman Volume 9, Nomor 2, Desember 2021 ; p-ISSN 2338-3186; e-ISSN 2549-1873; 185-200

A. M. Saifulloh and M. Darwis, "MANAJEMEN PEMBELAJARAN DALAM MENINGKATKAN EFEKTIVITAS PROSES BELAJAR MENGAJAR DI MASA PANDEMI COVID-19 Ahmad," Bidayatuna, vol. 03, no. 02, pp. 286-311, 2020.

A. Sadikin and A. Hamidah, "Pembelajaran Daring di Tengah Wabah Covid-19 ( Online Learning in the Middle of the Covid-19 Pandemic )," BIODIK J. Ilm. Pendidik. Biol., vol. 6, no. 02, pp. 214-224, 2020.

A. S. Syarifudin, "IMPELEMENTASI PEMBELAJARAN DARING UNTUK MENINGKATKAN MUTU PENDIDIKAN SEBAGAI DAMPAK DITERAPKANNYA SOCIAL DISTANCING," J. Pendidik. Bhs. dan Sastra Indones. pemerintah, vol. 5, no. 1, pp. 31-34, 2020.

R. Yunitasari and U. Hanifah, "Pengaruh Pembelajaran Daring terhadap Minat Belajar Peserta didik pada Masa COVID-19," Ria Yunitasari1, Umi Hanifah2, vol. 2, no. 3, pp. 232-243, 2020.

N. Septantiningtyas, "PENGARUH PEMBELAJARAN DARING DENGAN APLIKASI GOOGLE CLASS TERHADAP HASIL BELAJAR MAHASISWA," J. Pendidik. agama islan edureligia, vol. 2, no. 2, pp. 1-5, 2018.

Mastura and R. Santaria, "Dampak Pandemi Covid-19 terhadap Proses Pengajaran bagi Guru dan Peserta didik," J. Stud. Guru dan Pembelajaran, vol. 3, no. 2, pp. 289-295, 2020.

Ericha Windhiyana Pratiwi, "DAMPAK COVID-19 TERHADAP KEGIATAN PEMBELAJARAN ONLINE DI SEBUAH PERGURUAN TINGGI KRISTEN DI INDONESIA," Perspekt. Ilmu Pendidik., vol. 34, no. 1, pp. 1-8, 2020, doi: 10.21009/pip.341.1.

B. Warsita, "MOBILE LEARNING SEBAGAI MODEL PEMBELAJARAN YANG EFEKTIF DAN INOVATIF," J. Teknodik, vol. XIV, no. 1, pp. 62-73, 2010.

O. I. Handarini, S. S. Wulandari, and Program, "Pembelajaran Daring Sebagai Upaya Study From Home (SFH) Selama Pandemi Covid 19 Oktafia," J. Pendidik. Adm. Perkantoran, vol. 8, no. 3, pp. 496-503, 2020.

P. Wahyono, H. Husamah, and A. S. Budi, "Guru profesional di masa pandemi COVID-19: Review implementasi, tantangan, dan solusi pembelajaran daring Poncojari," J. Pendidik. PROFESI GURU, 
vol. 1, no. 1, pp. 51-65, 2020.

Asmuni, "Problematika Pembelajaran Daring di Masa Pandemi Covid-19 dan Solusi Pemecahannya," Penelit. dan Pengemb. Pendidik., vol. 7, no. 4, pp. 281-288, 2020.

http://www.teropongtimur.co.id/2020/12/smk-nurul-jadid-menbisapiagam-dimasa.html. Penyerahan piagam penghargaan yang bertempat di Grand Savero Hotel Bogor, selasa, pada 07/12/2020 R. T. Handayani, D. Arradini, A. T. Darmayanti, A. Widiyanto, and J. T. Atmojo, "Pandemi covid-19, respon imun tubuh, dan herd immunity," J. Ilm. Permas J. Ilm. STIKES Kendal, vol. 10, no. 3, pp. 373-380, 2020.

Prawiyogi, A. G., Purwanugraha, A., Fakhry, G., \& Firmansyah, M. (2020). Efektifitas Pembelajaran daring Terhadap Pembelajaran Peserta didik di SDIT Cendekia Purwakarta. Jurnal Pendidikan Dasar.

Nabila Hilmy Zhafira, Yenny Ertika, C. (2020). Pembelajaran daring di masa Pandemi. Jurnal l Bisnis Dan Kajian Strategi Manajemen.

Napitupulu, R. M. (2020). Dampak pandemi Covid-19 terhadap kepuasan pembelajaran daring. Jurnal Inovasi Teknologi Pendidikan. https://doi.org/10.21831/jitp.v7i1.32771

Azzahra, N. F. (2020). Mengkaji Hambatan Pembelajaran daring di Indonesia di Masa Pandemi Covid-19. Center for Indonesia Policy Studies.

Sari, D. R., \& Amrozi, F. (2020). Analisis Efektivitas Pembelajaran daring (PD) di Politeknik Penerbangan Surabaya. Jurnal Penelitian.

Suharwoto, G. (2020). Pembelajaran Online di Tengah Pandemi Covid19, Tantangan yang Mendewasakan.

Sadikin, A., \& Hamidah, A. (2020). Pembelajaran Daring di Tengah Wabah Covid-19: (Online Learning in the Middle of the Covid-19 Pandemic). BIODIK: Jurnal Ilmiah Pendidikan Biologi.

Maknuni, J. (2020). Pengaruh Media Belajar Smartphone Terhadap Belajar Peserta didik Di Era Pandemi ( The Influence of Smartphone Learning Media on Student Learning in The Era Pandemi. IDEAL: Indonesian Education Administration and Leadershio Journal.

Fathimah, S., Sidik, S., \& Rahman, R. (2020). Google docs sebagai solusi pengerjaan tugas kelompok dalam pembelajaran daring di tengah pandemi covid 19. Jurnal Ilmu Sosial Dan Pendidikan.

Knowles, M. S. (1980). THE MODERN PRACTICE OF ADULT EDUCATION , From Pedagogy to Andragogy What Is Andragogy? Business. 
Creswell, J. W. (2003). Creswell, J.W. (2003). Chapter One, "A Framework for Design." Research Design Qualitative Quantitative and Mixed Methods

https://doi.org/10.3109/08941939.2012.723954

Sungkono, S. (2005). PEMBELAJARAN DARING BERBASIS

TEKNOLOGI INFORMASI. MAJALAH ILMLAH PEMBELAJARAN.

Usman, U. (2019). KOMUNIKASI PENDIDIKAN BERBASIS BLENDED LEARNING DALAM MEMBENTUK

KEMANDIRIAN BELAJAR. Jurnal Jurnalisa.
https://doi.org/10.24252/jurnalisa.v4i1.5626

Handayani, A. S., \& Ariyanti, I. (2020). Kemandirian Belajar Matematika

Peserta didik Smp Disaat Pandemi Covid-19. In UrbanGreen

Conference Proceeding ....

Christensen, J., \& Grant, M. (2007). How political change paved the way for indigenous knowledge: The Mackenzie valley resource management act. Arctic. https://doi.org/10.14430/arctic236

Mashud. (2015). Pendekatan Pembelajaran Pendidikan Jasmani Olahraga dan Kesehatan di Era Abad 21. Jurnal Multilateral.

Hidayat, D. R., Rohaya, A., Nadine, F., \& Ramadhan, H. (2020). KEMANDIRIAN BELAJAR PESERTA DIDIK DALAM PEMBELAJARAN DARING PADA MASA PANDEMI COVID -19 Program Studi Bimbingan dan Konseling, Universitas Negeri Jakarta SELF-REGULATED LEARNING OF STUDENTS STUDYING ONLINE. PERSPEKTIF Ilmu Pendidikan.

ZULFIKAR, Z. (2020). Rekonstruksi Pendidikan Keluarga Pada Masa Pandemi (Studi Pada Walimurid SMPI Al Hasanah Kota Bengkulu). Annizom.

Sulastrini, S., \& Muslihati, M. (2020). Rancangan Implementasi Kemandirian Belajar dalam Konteks Pandemi Covid-19 berdasarkan Perspektif Freedom to Learn Rogers. Prosiding Seminar Bimbingan Dan Konseling.

Jusuf, H., Sobari, A., \& Fathoni, M. (2020). Pengaruh Pembelajaran daring Bagi Peserta didik SMA Di Era Covid-19. Jurnal Kajian Ilmiah. https://doi.org/10.31599/jki.v1i1.212.

Wawancara dengan Guru SMKNJ Nurul Iman 2021

Wawancara dengan Guru SMKNJ Abdul Manaf 2021

Wawancara dengan Guru SMKNJ Mahfudz 2021 